\title{
Production of organic fertilizer from poultry feather wastes excluding the composting process
}

\author{
Przemysław Tronina, Fabiola Bubel \\ Poltegor-Institute, Institute of Surface Mining, Wrocław, Poland, e-mail: fabiola.bubel@igo.wroc.pl
}

\begin{abstract}
Chicken feathers generated in large quantities by the poultry industry are hazardous for the natural environment because of their poor digestibility and their potential as a source of microbiological pathogens. Currently, the main method of feather waste management is the production of feather meal by steam pressure cooking. This technology requires a high energy input. The high costs of hydrothermal degradation of these wastes are conducive to finding other alternative possibilities of poultry wastes management. This paper describes the feather-utilization method with calcium oxide treatment in a rotational reactor, which leads to the production of organic-mineral fertilizers. The effectiveness of this method has been tested in chemical and microbiological analyses. The results of the study confirm the possibility of the environmental usage of utilization-products.
\end{abstract}

Keywords: organic fertilizer, feather utilization, post-slaughter wastes.

Presented at VII Conference Wasteless Technologies and Waste Management in Chemical Industry and Agriculture, Międzyzdroje, 12 - 15 June, 2007.

\section{INTRODUCTION}

Commercial poultry processing is a sector of industry which generates large quantities of organic by-products. It is estimated that inedible wastes generated in poultry slaughterhouses constitute about $89 \%$ of all by-products from poultry processing $\mathbf{1}$. Feather wastes are a particularly serious problem. Large quantities of this waste are generated throughout the world each year.

Feathers constitute up to $10 \%$ of the total chicken weight, reaching more than $7,7 \times 10^{8} \mathrm{~kg} / \mathrm{year}$ as a by-product of the poultry industry ${ }^{2}$. Feathers, because of their high keratins content, are insoluble, poorly susceptible to digestion by proteolytic enzymes and chemical- or physical factors ${ }^{3}$. High resistance to degradation and a diversity of present microflora, including pathogenic microorganisms, means that feather wastes have become an environmental problem. Because of the storage problems and the microbiological threat, feather wastes should be treated quickly.

Currently, the main management method of feather byproducts is the production of feather meal, which is used as a supplement for animal feedstuffs. Feathers are processed in approved utilization plants by steam pressure cooking. The utilization method requires high financial outlays because of the high energy input which must be applied to keratins denaturation ${ }^{4}$.

Biotechnological methods involving micro-organisms and their enzymes may be applied to feather-structure degradation as an alternative to the current technology5. Research in this area is being conducted by a lot of research centers locally and worldwide but biotechnological methods are not applied on a commercial scale.

A cheap and easy way of feather-utilization is composting with manure, but it is a long-drawn-out process which must meet the requirements of the veterinaryinspection, including a closed composting field with sewage carry systems and periodic microbiological tests. The biggest problem for composting is odour emission and long endurance. This process does not guarantee the destruction of keratin fibers or of pathogenic organisms.

A lack of easy and economically attractive methods for feather wastes utilization leads us to find a new effective technology which can assure the common use of utilization products.

This paper presents an idea for feather-waste utilization with calcium oxide treatment. The aim of this study was to obtain organic fertilizer from poultry feathers which meets the chemical and microbiological requirements determined for organic and mineral-organic fertilizers specified in the Act of 26 July 2000 concerning fertilizers and fertilizing (Dz. U. Nr 89, poz. 991) with further changes $^{6}$ and the Decree of the Minister of Agriculture and Rural Development of 1 June 2001, concerning the execution of some regulations of the act concerning fertilizers and fertilizing (Dz. U. Nr 60, poz. 615) with further changes?

\section{UTILIZATION MATERIALS}

In all three poultry feather utilization processes, calcium oxide and brown coal as a mineral fertilizing additive were used. The utilized compositions were differentiated only in terms of the amount of added calcium oxide and water. Detailed information on materials content in each composition is presented in Table 1.

The post-slaughter poultry feathers, containing around $70 \%$ water, came from the poultry slaughter-house in Bielany Wrocławskie, calcium oxide came from Company Górażdże Group in Opole and fine brown coal came from the brown coal mine in Sieniawa.

\section{EXPERIMENTAL ROTATIONAL REACTOR}

In order to conduct studies, an experimental rotational reactor was designed and constructed. The device was made on the basis of H095 concrete mixer of $\mathrm{V}=200$ $\mathrm{dm}^{3}$. The charging hole is fastened with a closure head equipped with four filters containing active carbon to absorb odours. To eliminate the losses of heat emitted 
Table 1. Utilization compositions

\begin{tabular}{|c|c|c|c|}
\hline \multirow{2}{*}{ INGREDIENT } & \multicolumn{3}{|c|}{ CONTENT IN UTILIZATION COMPOSITION } \\
\cline { 2 - 4 } & PP-1 & PP-2 & PP-3 \\
\hline POULTRY FEATHERS & $30.0 \mathrm{~kg}$ & $30.0 \mathrm{~kg}$ & $30.0 \mathrm{~kg}$ \\
\hline CALCIUM OXIDE & $2.1 \mathrm{~kg}(7 \%)$ & $3.0 \mathrm{~kg}(10 \%)$ & $3.6 \mathrm{~kg}(12 \%)$ \\
\hline FINE BROWN COAL & $3.0 \mathrm{~kg} \mathrm{(10 \% )}$ & $3.0 \mathrm{~kg} \mathrm{(10 \% )}$ & $3.0 \mathrm{~kg}(10 \%)$ \\
\hline WATER & $3.0 \mathrm{I}(10 \%)$ & $3.0 \mathrm{I}(10 \%)$ & - \\
\hline
\end{tabular}

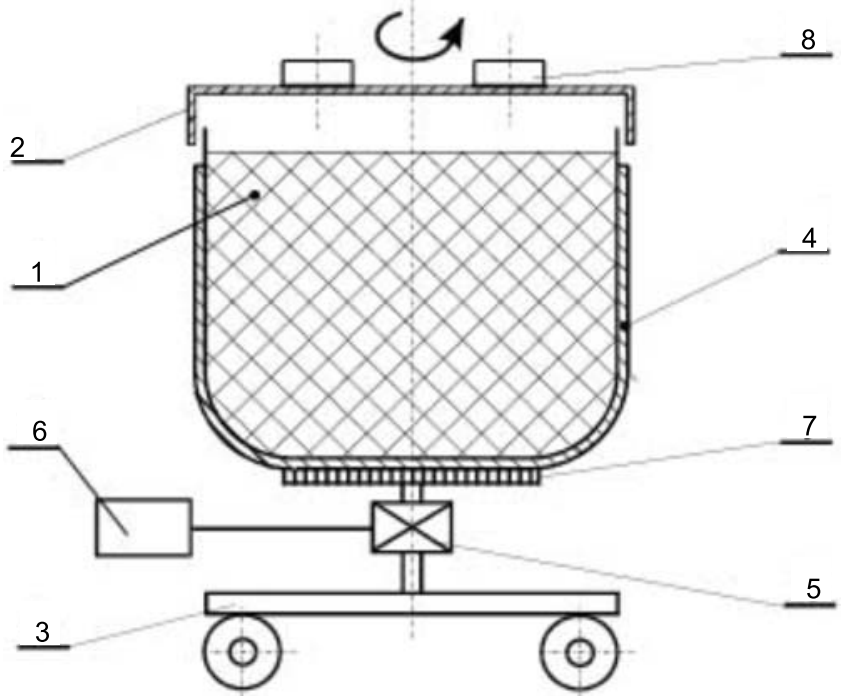

Figure 1. The scheme of the reactor


Figure 2. The scheme of the closure head

1 - reactor's tumbler

2 - closure head

3 - undercarriage

4 - polyurethane foam

5 - reactor's drive

6 - frequency converter

7 - toothed ring

8 - active coal filters

during the composting process, the tumbler was covered with an additional layer of polyurethane foam. The reactor was equipped with a VLT 2800 frequency converter that made it possible to modify the reactor's speed and sense of rotation. The scheme of the reactor is presented in Figs. 1 and 2.

\section{UTILIZATION PROCESS DESCRIPTION}

After filling the reactor with the components in proportions presented in Table 1., the closure head was sealed and the reactor was turned on. After initial mixing, the rotational speed of the reactor was established at the level of $15 \mathrm{rpm}$. The estimated time of calcium oxide transformation during the utilization was 2 hours. During the process, calcium oxide bound water from the post-slaughter poultry feathers in a hydration reaction. A lot of heat was released during the exothermic reaction of hydration causing the temperature to rise up to over $80^{\circ} \mathrm{C}$ due to the reaction scheme:

$\mathrm{CaO}+\mathrm{H}_{2} \mathrm{O} \rightarrow \mathrm{Ca}(\mathrm{OH})_{2}+\mathrm{Q}$

After terminating the process and cooling down the reactor, the final product of the utilization was unloaded, mechanically shredded and transferred to a storage prism.

\section{CHEMICAL AND MICROBIOLOGICAL TESTS}

In order to estimate the content of the fertilizing components, toxic metals and microbiological safety of the utilization products, the samples of those final preparations were tested at the Institute of Soil Science and Plant Cultivation in Puławy.

Chemical analyses were conducted according to internal laboratory procedures at the Central Laboratory of Chemical Analyses in Puławy. Microbiological studies were performed at the Department of Agricultural Microbiology following the procedures based on norms PN-Z-19000-18 and PN-Z-19000-4'.

\section{RESULTS AND DISCUSSION}

The results of the chemical and microbiological tests of the final utilization products are presented in Tables 2 and 3.

A lot of heat was released during the exothermic reaction of ,slacking”. The high temperature $\left(>80{ }^{\circ} \mathrm{C}\right)$ and strongly alkaline environment $(\mathrm{pH}>12)$ during the process caused the inactivation of pathogens in feathers. The conducted microbiological test showed that the proposed utilization technology efficiently inactivates Salmonella pathogens whose presence in fertilizers is forbidden according to the current law. Also, no live eggs of the invasive parasites Ascaris spp., Trichuris spp. or Toxocara spp. were found, which confirms the effectiveness of the technology used.

Utilization products were also characterized by the several times lower content of toxic elements than determined in the Decree of the Minister of Agriculture and Rural Development of 1 June 2001, concerning the execution of some regulations of the act concerning fertilizers and fertilizing (Dz. U. Nr 60, poz. 615) with further changes. The content of copper was on average 60-times lower and nickel 9-times lower than the amounts described in the regulations.

Essential nutrient elements, such as nitrogen, phosphorus, potassium, magnesium, calcium and sodium, were found in the final utilization products, which may suggest a positive influence of those preparations for plant growth. Additionally, their alkaline reaction gives those preparations an additional feature, that of soil deacidification.

The high content of the organic matter $(>50 \%)$ in those products is also worth mentioning. Its positive influence reveals itself in gathering the nutrient components and stops them from being washed out. As an additional 
Table 2. The results of the chemical tests of the final utilization products

\begin{tabular}{|c|c|c|c|c|}
\hline \multirow{2}{*}{ Test } & \multirow{2}{*}{ units } & \multicolumn{3}{|c|}{ Sample } \\
\hline & & PP-1 & PP-2 & PP-3 \\
\hline $\mathrm{pH}$ in $\mathrm{H}_{2} \mathrm{O}$ & $\mathrm{pH}$ & 12.5 & 12.6 & 12.6 \\
\hline Dry mass content & $\%$ & 36.33 & 34.20 & 38.07 \\
\hline Water content & $\%$ & 63.67 & 65.80 & 61.93 \\
\hline \multicolumn{5}{|c|}{ Content in dry mass: } \\
\hline $\begin{array}{l}\mathrm{N}-\text { total } \\
\text { containing: }\end{array}$ & $\%$ & 10.60 & 8.96 & 9.51 \\
\hline $\mathrm{N}-\mathrm{NH}_{4}$ & $\%$ & 0.25 & 0.35 & 0.47 \\
\hline $\mathrm{P}_{2} \mathrm{O}_{5}$ & $\%$ & 0.27 & 0.27 & 0.30 \\
\hline $\mathrm{K}_{2} \mathrm{O}$ & $\%$ & 0.15 & 0.10 & 0.12 \\
\hline $\mathrm{CaO}$ & $\%$ & 13.40 & 20.10 & 19.00 \\
\hline $\mathrm{MgO}$ & $\%$ & 0.27 & 0.16 & 0.17 \\
\hline $\mathrm{Na}_{2} \mathrm{O}$ & $\%$ & 0.13 & 0.11 & 0.11 \\
\hline $\begin{array}{l}\text { Organic substance } \\
\text { (losses during } \\
\text { calcination in } 550^{\circ} \mathrm{C} \text { ) }\end{array}$ & $\%$ & 71.90 & 57.16 & 57.26 \\
\hline Ash & $\%$ & 28.10 & 42.84 & 47.74 \\
\hline $\mathrm{Cd}$ & $\mathrm{mg} / \mathrm{kg}$ & below 0.30 & below 0.30 & below 0.30 \\
\hline $\mathrm{Cr}$ & $\mathrm{mg} / \mathrm{kg}$ & 3.13 & 3.04 & 2.73 \\
\hline $\mathrm{Cu}$ & $\mathrm{mg} / \mathrm{kg}$ & 6.76 & 6.18 & 6.46 \\
\hline $\mathrm{Ni}$ & $\mathrm{mg} / \mathrm{kg}$ & 2.51 & 3.13 & 3.32 \\
\hline $\mathrm{Pb}$ & $\mathrm{mg} / \mathrm{kg}$ & below 5.00 & 6.44 & 5.33 \\
\hline $\mathrm{Zn}$ & $\mathrm{mg} / \mathrm{kg}$ & 90.50 & 88.50 & 93.60 \\
\hline $\mathrm{Hg}$ & $\mathrm{mg} / \mathrm{kg}$ & 0.01 & 0.02 & 0.02 \\
\hline
\end{tabular}

Table 3. The results of the microbiological test of the final utilization products

\begin{tabular}{|c|c|c|c|c|}
\hline \multirow{2}{*}{ Sample } & \multicolumn{4}{|c|}{ Test } \\
\cline { 2 - 5 } & $\begin{array}{c}\text { Salmonella } \\
\text { in } 10 \mathrm{~g} \text { of } \\
\text { product }\end{array}$ & $\begin{array}{c}\text { Number of live eggs of Ascaris } \\
\text { spp. in 1 kg of dry mass }\end{array}$ & $\begin{array}{c}\text { Number of live eggs of Trichuris } \\
\text { spp. in 1 kg of dry mass }\end{array}$ & $\begin{array}{c}\text { Number of live eggs of Toxocara } \\
\text { spp. in } 1 \mathrm{~kg} \text { of dry mass }\end{array}$ \\
\hline PP-1 & None found & None found & None found & None found \\
\hline PP-2 & None found & None found & None found & None found \\
\hline PP-3 & None found & None found & None found & None found \\
\hline
\end{tabular}

source of organic matter, especially humic acids, positively influencing physical and sorption characteristics of the products, fine brown coal was added ${ }^{\mathbf{1 0}}$.

Directly after emptying the reactor, the water content in the final utilization product was abundant. Storing in a prism makes it possible for excess water to evaporate and as a result improve the consistency of the preparation, which is vital for soil application.

Based on the conducted tests, the final utilization products received a positive opinion from the Institute of Soil Science and Plant Cultivation in Puławy referring to the environmental usage of those preparations. The real fertilizing properties should be a matter of further vegetative field tests.

\section{CONCLUSIONS}

1. The presented technology of poultry feather utilization makes it possible to generate a product that fulfils the requirements determined for the organic and mineralorganic fertilizers specified in the Act of 26 July 2000, concerning fertilizers and fertilizing (Dz. U. Nr 89, poz. 991) with further changes and the Decree of the Minister of Agriculture and Rural Development of 1 June 2001, concerning the execution of some regulations of the act regarding fertilizers and fertilizing (Dz. U. Nr 60, poz. 615) with further changes. Final fertilizing preparations received a positive opinion from the Institute of Soil
Science and Plant Cultivation in Puławy, referring to the environmental usage of those products.

2. Minimum addition of $7 \%$ of calcium oxide made it possible to generate the products meeting sanitary demands.

3. The high content of the slowly released nitrogen and other nutrient components along with the high $\mathrm{pH}$ of the final products may suggest a good fertilizing usability of the utilization products.

4. Technology described in this paper may be an economical alternative to the recently used methods of feather utilization.

The results presented in this paper were obtained within the purposeful project no 6T092005C/06541 „Sludge and organic wastes utilization technology development" financed by Ministry of Science and Higher Education.

\section{LITERATURE CITED}

1. Rosik-Dulewska, Cz., (2006). Podstawy gospodarki odpadami, Wydawnictwo Naukowe PWN, Warszawa.

2. Grazziotin, A., Pimentem, F.A., de Jong, E.V. \& Brandelli, A., (2006). Nutritional improvement of feather protein by treatment with microbial keratinase, Animal Feed Science and Technology, 126, 135 - 144.

3. Rodziewicz, A. \& Laba, W., (2006). Keratyny $i$ ich biodegradacja, Biotechnologia, 2 (72). 
4. Praca zbiorowa pod redakcją doc. dr hab. Tadeusza Grabowskiego, (1993). Technologia mięsa drobiowego, Wydawnictwa Naukowo-Techniczne, Warszawa.

5. Onifade, A.A, Al-Sane, N.A., Al-Musallam, A.A. \& AlZarban, S., (1998). A review: Potentials for biotechnological applications of keratin-degrading microorganisms and their enzymes for nutritional improvement of feathers and other keratins as livestock feed resources, Bioresource Technology, 66, 1-11.

6. Ustawa o nawozach i nawożeniu z dnia 26 lipca $2000 \mathrm{r}$. (Dz. U. Nr 89, poz. 991) z późniejszymi zmianami.

7. Rozporządzenie Ministra Rolnictwa i Rozwoju Wsi z dnia 1 czerwca 2001 r. w sprawie wykonania niektórych przepisów ustawy o nawozach i nawożeniu (DzU nr 60, poz. 615) z późniejszymi zmianami.

8. PN-Z-19000-1 Ocena stanu sanitarnego gleby Wykrywanie bakterii z rodzaju Salmonella.

9. PN-Z-19000-4 Ocena stanu sanitarnego gleby Wykrywanie jaj pasożytów jelitowych.

10. Maciejewska, A., (1998). Wegiel brunatny jako źródto substancji organicznej $i$ jego wptyw na wtaściwości gleb, Oficyna Wydawnicza Politechniki Warszawskiej, Warszawa. 